\title{
Leaders in ethics education
}

\author{
Bahaa Darwish ${ }^{1}$ (D)
}

Published online: 20 March 2017

(C) Springer International Publishing AG 2017

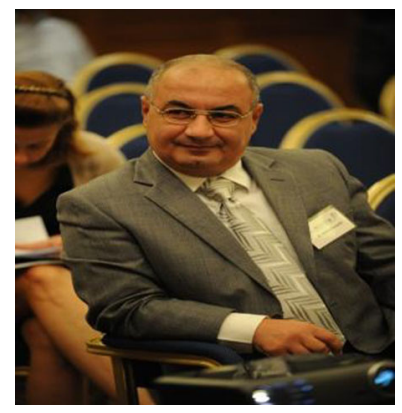

In 1980, Darwish was graduated in Alexandria University where he studied philosophy in the College of Arts. In 1987, he got his MA in philosophy. In 1993, he got a $\mathrm{PhD}$ scholarship to Germany and returned in 1995 to Egypt where he was awarded the $\mathrm{PhD}$ title and was appointed as a lecturer in Minia University MU (South of Cairo).

In 2003, he was promoted to Associate professor, and left Minia University to work in the United Arab Emirates University (UAEU) for three running semesters as a visiting professor teaching logic and methodology.

From September 2004 to September 2012, Darwish joined Qatar University (QU), College of Arts and Sciences, where he taught a variety of courses in philosophy. In August 2010, he got promoted to full Professor of Philosophy. In September 2012, he joined MU back as a professor of philosophy, and since January 2014 he is the head of the department of philosophy there.

Ethics is one of the courses he used to teach in Minia university before leaving to UAE. In Qatar university, from 2005 to 2012, he incorporated some issues related to bio/medical ethics and media ethics as part of the course "Introduction to Philosophy".

Bahaa Darwish

elsayed.baha@mu.edu.eg

1 Minia University, Minia, Egypt 
In the new study plan being prepared now for the philosophy department, MU, introduction to applied ethics and bioethics are two courses that will be given in the department.

Dr. Darwish participated in numerous local, regional and international conferences covering a wide range of philosophical issues: theory of knowledge, philosophy of mind, philosophy of language, critical thinking, bioethics and ethics of science and technology. Dr. Darwish has initiated the course "Critical Thinking" in 2006 in QU where he taught it for several years (in English). In 2009, he participated in preparing "QU Handbook for Research Ethical Rules and Regulations".

Dr. Darwish has published several books and papers in both Arabic and English. Among those in English are: "Two Points against Naturalized Epistemology" (1998), available online: http://www.bu.edu/wcp/Papers/TKno/TKnoDarw.htm; "Rethinking Utilitarianism” Teaching Ethics Journal 2009; 10 (1):87-109;“What Should Families Consider when Deciding for an Incompetent Patient? A Commentary from Egypt" Asian Bioethics Review 2013; 5 (2): 149-151; and 'Arab Perspectives' in H.A.M.J. ten Have, B. Gordijn (eds.), Handbook of Global Bioethics, Springer; Dordrecht, 2013: 269-291; 'How Effective Can Ethics Education Be' (2015) in H.A.M.J. ten Have, (ed.), Bioethics Education in a Global Perspective, Advancing Global Bioethics 2014; Springer: Dordrecht: 109-117; "Promoting the Future of Bioethics" in German Solinis (ed.), Global Bioethics: What for? 2015, UNESCO, pp. 107-110.

Since 2006, he has been a temporary expert for UNESCO in the field of Ethics of science and technology. He contributed to the research published by the UNESCO Cairo Office 2011 titled "Ethics and Law in Biomedicine and Genetics: An Overview of National Regulations in the Arab States". Available online http://unesdoc.unesco. org/images/0021/002152/215207e.pdf He is also considered one of the international experts UNESCO depends on in conducting the Ethics Teacher Training Courses (ETTC): one of the main components of UNESCO's Bioethics professional capacitybuilding programme.

In 2010, Dr. Darwish participated in founding the International Association for Education in Ethics (IAEE), of which, since May 2012, he is a board member. In December 2011, he also participated in founding the Bioethics Network on Women's Issues in the Arab World BiNWIAR, of which, since August 2013, he is a board member. In 2016, he was elected as one of its two vice-presidents (http://bioethicsnetwork. wordpress.com).

\section{You are one of the leaders of ethics teaching in the Arab world ethics. Why did you become interested in ethics teaching?}

I do not consider myself one of the leaders of teaching ethics in the Arab world. However, you may say that I discovered relatively early enough, in the Arab world, the importance of teaching applied ethics. This was in 2005 when I was teaching in Qatar University. Since there was, then, no stand-alone course in any branch of applied ethics to teach in the university, I incorporated some issues of biomedical and media ethics in the course "Introduction to Philosophy" that I was then teaching. As specialized in philosophy, I have been interested in ethics teaching since I started teaching in Minia university in 1995. In applied ethics, I became interested in teaching such branches out 
of my conviction that education of applied ethics is necessary to raise students' awareness of the ethical issues that arise out of the development of biological and technological sciences. Having raised the students' awareness of the ethical issues, the next step is to teach them how to critically and reflectively think of such issues and rationally deal with them.

\section{Who were the teachers who have inspired you to choose a professional career in ethics education? What have you learned from them?}

I cannot name one specific person and say it was he who inspired me to teach ethics. It was my readings in ethics rather than anything else that has directed me to the importance of learning ethics for people's practical and professional life, and thus motivated me to teach ethics. One of the books that inspired me and turned my attention towards the importance of ethics of science is The Ethics of Science: An Introduction by David B. Resnik, which I read in Arabic translated by Dr. Abdelnour Abdelmenem, translation revised by Professor Yomna Elkhouly, published in Aalam Elme'refa (316), Kuwait, 2005. My conviction of the importance of teaching ethics is augmenting in time and becoming greater day by day.

\section{What is your view of the current status of ethics teaching in the world?}

Ethics teaching was once the concern primarily of philosophers and theologians. Helped by the media that give room to public debates about the ethical dimensions of nearly every issue, the trend to teach ethics is internationally increasing. This is evidenced from the increasing number of ethics courses delivered in the universities, as well as the increasing number of professional schools that commit themselves to teaching ethics. International bodies, such as UNESCO, have also helped raising the awareness of the need to expand ethics education throughout the world. UNESCO has launched the Ethics Teachers Training Courses - a five days course to train bioethics educators on how and what to teach to their students- as a part of its commitment to provide assistance in building robust national bioethics infrastructure As evidence of the increasing awareness of the importance of ethics education and of the success of such international course, there is an increasingly global demand for such course.

\section{What is your view of ethics teaching currently in the Arab world? What is similar and what is different compared to the rest of the world?}

Ethics teaching in the Arab world focuses in general either on ethical theories throughout history, since Plato and Aristotle till now, thus taught in philosophy departments, or in teaching medical ethics in colleges of medicine, mainly in departments of forensic medicine. Other branches of applied ethics such as bioethics. Business ethics, environmental ethics, or media ethics are relatively new and in many Arab universities are not part of their educational curricula. 
These courses are still not developed because they are not taught by the right persons. I mean that they are not taught by specialized ethicists, but rather by environmentalists or biologists (in the case of environmental ethics), professors of media (in the case of media ethics), professors of forensic medicine to teach medical ethics, etc. Most of these instructors are not qualified enough to teach ethics. They do not have independent qualification in ethics. In case of medical ethics, for instance, there is no specialization in medicine among its branches called ethics, in the sense that if a college member writes a research in medical ethics, it cannot be considered one of the researches with which they can get promoted. This discourages faculty members from doing research in ethics and teach ethics thus as an additional course to their specialisation not as professionals who have sufficient background in ethics and developing it in time through research.

\section{Can you describe your teaching activities? Who are your students?}

As a philosophy instructor who is specialized in modern and contemporary western philosophy, I teach my undergraduate students such branch of philosophy: modern and contemporary western philosophy. Ethics is taught within such courses as a part of philosophers' contribution such as Kant, Thomas Moore, and John Stuart Mill. So, you can say that, so far, normative ethics is given the considerable part of ethics taught in the curriculum. However, throughout the four years of schooling, there is an annual course called "Arab and Western Specialised Texts" whose aim is to get students familiar with the original philosophical texts in their mother language. In such course, I teach texts pertaining to bioethics. My students show more interest in such course than in normative ethics. They get more engaged in the activities of such course than the one in normative ethics since the topics discussed here are real life topics and the ethical issues discussed are so linked to, and sometimes challenge, their customs, traditions and beliefs. As another evidence of the interest that my students show for ethics, one of my postgraduate students chose Just War Ethics as a topic for his $\mathrm{PhD}$ dissertation. Another new colleague in our department, who used to be one of my students, has recently finished a research on Martha Nussbaum's Theory of Justice and another on Ethics of sex selection.

In my department of philosophy, Minia University, we have designed a new study plan where "bioethics" and "introduction to applied ethics" will be delivered for the first time starting from next or the following year. Such courses will be the first applied ethics courses to be given in Egypt in colleges of humanities.

Equally, if we go back to 2009, 2010 when I used to teach Business ethics to students of the College of business and economics, Qatar University, I recall how much interested they were in such course as used to appear in their engagement and in the questionnaires they used to fill evaluating their courses.

I would attribute such interest in ethics in the university to the wider growing interest of ethics in the society as a whole. Issues such as the role of the media in affecting people's beliefs after the so called revolution of 2011 in Egypt and what codes of ethics should media people follow are much more debated than before. 


\section{In your view, what are the core objectives of ethics education?}

The first important objective of ethics education is to raise people's sensibility towards ethical issues. This is an important step towards their thinking how to deal with them. Students should understand that ethics is not subjective, in the sense that ethical issues cannot be decided through feelings, imitation or intuitions, but through acquiring, thus adopting a rational approach. Ethics education is the vehicle to provide students with such understanding. Once they use the rational approach in tackling ethical issues, this may help turning their beliefs into actions, which I consider the utmost objective of learning ethics. Another objective is that students should understand the relation between ethics and law. Students should understand that ethics complements what laws cover. Laws cannot legislate every life issue.

Equally, students should also understand that there is no identity between ethics and religion: religious and non-religious communities have their own ethics. Ethics is also historically prior to religion.

\section{What is your vision for ethics education? Will it expand and become more important? Will it be sidelined because of financial or political pressures? Will it be associated with global concerns and growing awareness of global ethical problems?}

Ethics teaching, specifically applied ethics, will remain representing the awareness tool of the need to continuously harness scientists' non-stop curiosity and making sure that their scientific and technological products are directed towards the good of mankind. Teaching ethics in general will remain the tool that helps filtering all sorts of conduct, determining what sort of conduct can lead to the preservation of the human values and the human rights' principles long fought for in face of any potential financial or political pressures. In every partof the world, ethics education ought to find and focus on the common ethical problems in search of global and human solutions of them.

\section{What kinds of activities are needed to expand ethics education at the global level and in your region? How should they be promoted?}

Institutes and foundations offering grants should understand that expanding ethics education is important, so they should be encouraged to allot a considerable portion of their funding for granting ethics-based courses and programs. This is an important step to encourage faculty members and colleges to introduce, or expand ethics education.

Professional schools - providing ethics courses- should be encouraged to introduce ethics as an integrated part of the curriculum, not as standing-alone courses. This is because introducing ethics as a stand-alone course may give students the impression that ethics is an independent subject that is not necessarily associated with the field of knowledge they are learning, when it is mainly delivered to teach students how to deal with the ethical issues related to their field. The only main difficulty in applying such approach is that a big number of faculty members should be trained to teach ethics, 
which is not the case in many universities. Therefore, continuous training courses on teaching ethics ought to be regularly given to faculty members whose curricula ought to have an ethics integrated part.

Networks of ethics professionals, databases for ethics courses or learning materials should be designed and made available to all ethics teachers and those interested in ethics all over the world as a resource hub. Such resource hub can motivate interest in ethics in those who are reluctant to teach ethics. It can also facilitate the work of new teachers of ethics by providing them with sufficient ethics teaching material, and by linking them in a professional experts network to be able to get consultation from such experts on any issue related to what to teach and how to teach.

Successful stories of ethics teaching should also be published and disseminated publicly to serve as a guide that can benefit ethics teachers and professional schools that deliver ethics courses. 